\title{
IS CORPORATE GOVERNANCE AND INTELLECTUAL CAPITAL DISCLOSURE RELATED? A SRI LANKAN CASE
}

\author{
Pratheepkanth Puwanenthiren \\ University of Jaffna, Sri Lanka \\ Email - ppratheepkanth84@yahoo.com
}

\begin{abstract}
This study investigates the association between corporate governance and intellectual capital (IC) disclosure, controlling for firm age and leverage, for a sample of 150 Sri Lankan listed firms. The independent variables comprise various forms of corporate governance attributes: board size, board independent, board meetings and CEO role duality. IC disclosure is measured by a disclosure index. Empirical analysis is conducted using correlation and linear multiple regression analysis. Findings from the empirical analysis indicate that associations between the corporate governance and IC disclosure are generally mixed. There is still no established and generally accepted Sri Lankan framework for IC disclosure, which could be a reason for inconsistency. Results of this study provide useful information for the accounting profession, the regulators and corporations on the effective exercise of corporate governance.
\end{abstract}

Keywords: corporate governance, intellectual capital, intellectual capital disclosure

\section{Introduction}

Corporate governance as a way in which suppliers of finance to corporations assure themselves of getting a return on their investment (Shleifer \& Vishny, 1997). The importance of corporate governance arises in a firm because of the separation between those who control and those who own the residual claims (Epps \& Cereola, 2008). McCullers and Schroeder (1982) argue that the agency theory assumes an opportunistic behaviour that is individuals want to maximise their own expected interests and are resourceful in doing so. There will be a conflict of interest between mangers and stakeholders (Macus, 2008). Agency theory suggests corporate 
governance as a mechanism to reduce these conflicts by monitoring managers' performance and aligning management's goals with those of the stakeholders (Brickley \& James, 1987). In this sense, one of the most recent and widely discussed issues in both the academic literature and the business press concerns with how to design corporate governance mechanisms to improve firm transparency and to solve the information asymmetry problem arising from the separation between ownership and control (Hidalgo, García-Meca, \& Martínez, 2011). The Intellectual capital (IC) disclosure becomes important to signal investors about affairs of firms in an intense globally competitive environment (Abeysekera, 2008). IC can give rise to agency problems as 'insiders' of firms can take advantage of such information to earn excess profits. Disclosure of IC in annual reports helps to make capital markets more efficient by reducing information asymmetry between 'insiders' and investors. Additionally, IC disclosure helps the capital market to provide a more accurate market capitalization of firms (Guthrie, Petty, Ferrier, \& Wells, 1999). Previous literature illustrates the relationship between corporate governance and voluntary disclosure (Eng \& Mak, 2003; Forker, 1992; Markarian, Parbonetti, \& Previts, 2007; McKinnon \& Dalimunthe, 1993) and output is also somewhat mixed (Abeysekera, 2008). The contextual settings of emerging markets differ vastly from those of developed market. It is argued that the emprircal findings of studies regarding devloped markets have limited applicability in emerging markets (Guest, 2008). The mixed outcomes in the extant literature and a dearth of emerging country studies suggest a significant gap in understanding corpoarte governance and IC disclsoure. This study seeks to fill this gap by examining the impact of corpoarte governance and IC disclsoure of the listed firms in Sri Lanka. Sri Lanka is an emerging economy it is still considered developing. Since the conclusion of the civil war in 2009, Sri Lanka has witnessed considerable economic progress despite some ongoing political issues. This study would hopefully benefit academics, researchers, policy-makers and practitioners of Sri Lanka and other similar countries through exploring the impact of corporate governance on IC disclosure, and pursuing strategies to improve the current status of it.

This paper is organised as follows: Section 3 presents a review of the empirical studies that investigate the association between corporate governance and IC disclosure; Section 4 addresses research methods; Section 5 reports the results and discussion; and Section 6 summarises the conclusion. 


\section{Corporate governance regulations for listed firms in Sri Lanka}

Corporate governance is a system by which business corporations are directed and controlled (Eng \& Mak, 2003). The corporate governance structures specify the distribution of rights and responsibilities among different participants in the corporation, such as the board, managers, shareholders and other stakeholders, and spells out the rules and procedures for making decisions on corporate affairs (Forker, 1992). Since the late 1980s corporate failures in Sri Lanka have also increased the attention on proper corporate governance, which is fundamental to the efficiency of the operation of capital markets (Guo \& Kga, 2012). The legal framework for corporate control was provided by the company act of Sri Lanka, enacted in 1982, which was based on the 1948 Companies Act of the United Kingdom. It included conduct of board proceedings, conduct of shareholder's meetings, and particulars regarding proxies, directors' reports, responsibilities of directors, auditors functions etc. (Azeez, 2015). The Sri Lanka witnessed many corporate failures in the late 1980s and early 1990s through to 2008, especially in the finance firms (Welford, 2007). The weak financial reporting and auditing structures were some of the underlying causes of these failures. In 1996, the Institute of Chartered Accountants of Sri Lanka (CA Sri Lanka) set up a committee to make recommendations relating to the financial aspects of corporate governance in Sri Lanka (CA, 2017). The first code, code of best practice on matters related to financial aspects of corporate governance, was issued in 1997 and was subsequently updated in 2003, 2008, 2013 and 2017. The principles of good corporate governance in Sri Lanka were established through voluntary and mandatory mechanisms designed to introduce good governance practices for all listed firms (CA, 2017).

\section{Literature review and hypotheses development}

The literature expresses the importance of the corporate governance as the determining element in corporate decisions. The corporate governance on IC disclosure have received considerable research interest (Beekes, Pope, \& Young, 2004; Wild, 1996). Cadbury (1992) defined corporate governance as the system by which companies are directed and controlled. It is concerned with the duties and responsibilities of a firm's board of directors to successfully lead the company, and their relationship with its shareholders and other stakeholder groups. In this section reviews the empirical foundations for the association between corporate governance and IC disclosure. 


\subsection{Board size}

The literature demonstrates that the composition of the board of directors is primarily based on size, which has a significant influence on the efficiency, effectiveness and supervision of management conduct (Eng \& Mak, 2003). Expanding number of directors provides an increased pool of expertise because larger boards are likely to have more knowledge and skills at their disposal. Besides, large boards may be able to draw on a variety of perspectives on corpoarte strategy and may reduce domination by CEO (Forbes \& Milliken, 1999; Goodstein, Gautam, \& Boeker, 1994). On the other hand, the board-size effect: increased problems of communication and coordination as group size increases, and decreased ability of the board to control management, thereby leading to agency problems stemming from the separation of management and control (Yermack, 1996). In Sri Lanka, the code of best practice on CA (2017) recommends that every public firm should be headed by an effective board, which should direct, lead and control the firm. Although, there is no precisely recommended size for a board. There is a question whether larger board would lead to more effective IC disclosures. Based on this discussion, Hypothesis 1 is:

$H_{1}$ : There is a significant relationship between the size of the board and IC disclosures.

\subsection{Independent directors}

According to the CSE (2013) listing guidelines, independent board members should not relate to a key employee, are independent from management, and have never worked at the firm or its subsidiaries, or for its consultants or major stakeholders. The intention is to ensure equity in decision-making strategies by gambling on the transparency of information (Hidalgo, García-Meca, \& Martínez, 2011). Agency theory suggests that a board comprised of a greater proportion of independent directors, due to their presumed independence, may theoretically lead to better firm performance (Jensen \& Meckling, 1976; Shleifer \& Vishny, 1997). Similarly, resource dependence theory argues that independent directors are likely to bring useful resources from other firms (Pfeffer, 1972). On the other hand, institutional theory argues that appointing independent members to the board may merely represent firms' attempts to comply with institutional pressures, and, therefore, may not necessarily result in better performance (Dimmaggio \& Powell, 1983). Bueno et al. (2004) consider that the number of independent members leads to greater supervision and to maximisation of the value of the firm (Bueno, Salvador, Rodríguez, \& Martín-deCastro, 2004). Based on this discussion, Hypothesis 2 is: 
H2: There is a significant relationship between the proportion of independent directors and IC disclosures.

\subsection{Boardmeetings}

The boards of directors carry out critical roles, and thus deemed to be an important corporate governance mechanism (Lipton \& Lorsch, 1992). The Sri Lankan best practices on CA (2017) in recent times suggest that board meetings should be held at least once in every quarter of financial year. Lipton and Lorsch (1992) suggest that the greater frequency of meetings is likely to result in superior performance. Although, Vafeas (1999) demonstrates that firms that are efficient in setting the right frequency of board meetings, depending on its operating context, will enjoy economies of scale in agency costs, and thereby enhance firm performance. The literature advises that there are various aspects of board meetings such as quality, role of the chairman and way the decisions that need to be considered in terms of the impact on firm endeavours (Van-den-Berghe \& Levrau, 2004). Based on this discussion, Hypothesis 3 is:

H3: There is a significant relationship between number board meetings and IC disclosures.

\subsection{CEO duality}

There has been extensive debate in both academic and practitioner forums over the effect of CEO duality on activities. Duality offers the clear direction on a single leader, and a concomitantly faster response to external events (Boyd, 1995). Prior literature acknowledges that the type of board leadership and role of the CEO can have an influence on firm performance (Jackling \& Johl, 2009). Using agency theory, it would be anticipated that the separation of the chairman and CEO roles leads to greater scrutiny of managerial behaviour and thus leads to better performance (Lorsch \& MacIver, 1989). An agency perspective the roles of CEO and chair of the board should be separated. On the other hand, existing literature is not consistent since it establishes that not all CEOs are equal nor do they seek the same things because, when they decide to diversify both their objectives and their conduct, they may be aligned differently in accordance with their new activities (Datta \& Rasheed, 1991; Ramanujan \& Varadarajan, 1989) Based on this discussion, Hypothesis 4 is:

H4: There is a significant relationship between CEO duality and IC disclosures. 


\subsection{Control variable}

The potential interaction between corporate governance and IC disclosure can be influenced by other firm factors including the ownership structure, firm size, profitability and other governance-related indicators such as overall board independence (Ahmed Haji, 2015). As a result, in addition to corporate governance, this study controls for other variables such as firm age and leverage according to the prior research (Li, Mangena, \& Pike, 2012).

\section{Research method}

This study lies within the positivism paradigm and adopts a quantitative approach. The population of interest in this study is (initially) the 291 listed firms on the Colombo Stock Exchange (CSE), as at February 2015. In selecting the population, this study excludes financial, investment and securities sector firms because their unique financial attributes, intensity of regulation, and/or intensive use of leverage are likely to confuse and/or foul the outcomes being studied. Also, the risk of missing data was minimised by excluding firms that were not listed the review period. After the eliminations, 150 Sri Lankan listed firms remained in the population. Data on corporate governance and firm performance were collected from secondary sources which were extracted from annual reports and the database from CSE. The quantitative data were analysed using SPSS (version 23.0) to produce descriptive statistics and regression analysis. In the empirical analysis, the data for independent variables are collected for 2016, providing for a one-year lag to the 2017 IC disclosure data. Thus, 2017-full-year data are used for IC disclosure data of Sri Lankan firms.

\section{Table 1: Corporate governance measures}

\begin{tabular}{|c|c|c|}
\hline Variables & Measures & Symbols \\
\hline \multicolumn{3}{|l|}{ Corporate governance } \\
\hline Board size & Number of directors & $\mathrm{BS}$ \\
\hline Independent directors & Non-Independent directors/total directors & ID \\
\hline Board meetings & Frequency of annual meetings & $\mathrm{BM}$ \\
\hline CEO duality & $\begin{array}{l}\text { Dummy variable equals } 1 \text { when CEO } \\
\text { doubles as board chair and } 0 \text { otherwise. }\end{array}$ & CEO dual \\
\hline
\end{tabular}


To measure IC disclosure, the study employ content analysis, a method that has been applied by prior literature in measuring ICD (Beattie \& Thomson, 2007; Li, Mangena, $\&$ Pike, 2012). The study apply framework tested by Li, Pike and Haniffa (2008), which provides comprehensive list of voluntary IC items divided into three categories such as human, relational and structural items.

\section{Table 2 : IC disclosure measures}

\begin{tabular}{llll}
\hline \multicolumn{1}{c}{ Human Capital } & \multicolumn{1}{c}{ Relational Capital } & \multicolumn{1}{c}{ Structural Capital } \\
\hline 1 & Number of employees & Customers & Intellectual property \\
2 & Employee age & Market presence & Process \\
3 & Employee diversity & Customer relationships & Management philosophy \\
4 & Employee equality & Customer acquisition & Corporate culture \\
5 & Employee relationship & Customer retention & Organization flexibility \\
6 & Employee education & Customer training \& & Organization structure \\
7 & Skills/know- & education & Organization learning \\
& how/expertise/knowledg & Customer involvement & Research \& development \\
& e & Company image/reputation & Innovation \\
8 & Employee work related & Company awards & Technology \\
& competences & Public relation & Financial dealings \\
9 & Employee work-related & Diffusion \& networking & Customer support function \\
& knowledge & Brands & Knowledge-based \\
10 & Employee & Distribution channels & infrastructure \\
& attitudes/behaviour & Relationship with suppliers & Quality management \& \\
11 & Employee commitments & Business collaboration & improvement \\
12 & Employee motivation & Business agreements & Accreditations (certificate) \\
13 & Employee productivity & Favourite contract & Overall \\
14 & Employee training & Research collaboration & infrastructure/capability \\
15 & Vocational & Marketing & Networking \\
\multicolumn{1}{c}{ qualifications } & Relationship with & Distribution network \\
16 & Employee development & stakeholders & \\
17 Employee flexibility & Market leadership & \\
18 Entrepreneurial spirit & & \\
19 & Employee capabilities & & \\
20 & Employee teamwork & & \\
21 & Employee involvement & & \\
with community & & \\
22 & Other employee features & &
\end{tabular}

Source: Li, Pike, and Haniffa (2008) 
The scoring of the financial reports against the checklist was performed manually by reading the whole financial reports. Each intellectual capital item was scored based on three presentational formats such as text, numerical and graphical, thus receiving a maximum of three points. This means that a company can score a maximum of 183 points (61 intellectual capital items x 3 formats). After scoring all 61 IC items in the three presentational formats, the IC disclosure score(s) for each company are computed as an index by dividing the sum items disclosed by the total number of items expected. For each firm the study created four disclosure indices to capture the overall intellectual capital (ICDI), human capital (HICDI), relational capital (RICDI) and structural capital (SICDI) (Li, Mangena, \& Pike, 2012).

In control variable, the potential interaction between corporate governance and IC disclosure can be influenced by other organisational elements (Lemmon \& Lins, 2003). As a result, in addition to corporate governance proxies, this study controls for other proxies such as firm age and leverage.

\section{Table 3: Control variables measures}

\begin{tabular}{|l|l|c|}
\hline \multicolumn{2}{|l|}{ Control variables } \\
\hline Firm age & Present year - incorporation year & FA \\
\hline Leverage & Borrowings/total assets & LE \\
\hline
\end{tabular}

\section{Results and discussion}

\subsection{Descriptive analysis}

As reported in Table 4, the average is 11.66, with a minimum of two and a maximum of 32. In Sri Lanka, the last code of best practice on corporate governance published by CA Sri Lanka (2017) recommends that every public firm should be headed by an effective board, which should direct, lead and control the company. Although there is no precisely recommended size for a board in Sri Lanka. From a resource availability perspective, bigger boards should be relatively more effective. Van den Berghe and Levrau (2004) suggest that increasing the number of board directors provides an increased pool of expertise and thus larger boards are likely to have more knowledge and skills at their disposal. Conversely, overly large boards can experience such issues as a lack of cohesion, coordination issues, and fractionalisation (Pratheepkanth, Hettihewa, \& Wright, 2016). The average proportion of independent director is 77.08 percent, suggesting that board directors in the majority of firms are comprised of 
directors who are independent. Also, firms seem to have met the requirements of the code of best practice on corporate governance, sample firms independence ranging from 18 to 89 percent. For the number of annual meetings, the average is 4.91 with a maximum and minimum of 9 and one, respectively. The Sri Lankan code of best practices on CA (2017) recommends firms to hold at least one board meeting once in every quarter of a financial year. The boards that meet more frequently would have more time to perform the role of monitoring the management process efficiently. As for the leadership of the board, in 60 percent of the firms, there exists duality between the chairperson and the chief executive officer (CEO) of the firm. The code of best practices on corporate governance (2017) makes no recommendation on whether or not both posts should be held by the same person, but it does recommend that in case of duality, a decision to combine both posts of chairman and CEO in one person should be justified and highlighted in the annual reports. The mean index for overall intellectual capital disclosure is 0.35 (minimum from 0.10 to maximum 0.91 ) which implies that 35 percent of items were disclosed. The study observes that human capital disclosure, relational capital disclosure and structural capital disclosure is $0.41,0.31$ and 0.29 respectively. These results indicate that Sri Lankan firms, on average, are aware of the importance of intellectual capital disclosure. The firms appear to provide slightly greater human capital disclosure (ranging from 0.12 to 0.98 ) than both with relational capital disclosure and structural capital disclosure. This results diverge from Abeysekera and Guthrie (2005) who conclude that the most reported accounting category was relational capital and the second most reported was human capital.

\section{Table 4: Descriptive analysis}

\begin{tabular}{|l|r|r|r|r|}
\hline & Minimum & Maximum & Mean & \multicolumn{1}{c|}{ SD } \\
\hline Board size & 2 & 32 & 11.66 & 4.97 \\
\hline Independent directors (\%) & 18.18 & 88.89 & 77.08 & 1857 \\
\hline Board meetings & 1 & 9 & 4.91 & 1.95 \\
\hline CEO duality & 0 & 1 & 0.60 & 0.492 \\
\hline Firm age & 3 & 13 & 7.57 & 2.280 \\
\hline Leverage & 9.09 & 66.67 & 35.08 & 13.57 \\
\hline Overall intellectual capital disclosure_ICDI & 0.10 & 0.91 & 0.35 & 0.159 \\
\hline Human capital disclosure_HICDI_______ & 0.12 & 0.98 & 0.41 & 0.262 \\
\hline Relational capital disclosure_RICDI & 0.00 & 0.89 & 0.31 & 0.206 \\
\hline Structural capital disclosure_SICDI & 0.06 & 0.93 & 0.29 & 0.204 \\
\hline
\end{tabular}




\subsection{Linear multiple regression results}

Table 2 shows that the predictions of the four proxies for intellectual capital disclosure are strong. Specifically, the $\mathrm{R}^{2}$ values indicate that 28.7, 15.1, 13.4 and 17 percent of the variability in, respectively, overall IC disclosure, human capital disclosure, structural capital disclosure and relational capital disclosure of Sri Lankan firms can be explained by the corporate governance. The F-statistics and significance levels (sig) show that these four models generate statistically significant outcomes. In most cases, the regression results in Table 5, the coefficients of those variables are significantly and positively related to IC proxies. Board size is found to be significant at the $5 \%$ on the all the IC disclosure proxies except human capital disclosure and structural capital disclosure which indicates that firms are able to share different knowledge and expertise about the potential benefits of releasing information towards hidden values of a firm. Board independence have a positive and significant impact on all measures of IC disclosure of these firms. It can be interpreted that increase in board independence has a beneficial effect on IC disclosure. Frequency of board committee meetings is found to have significant and positive effect on all IC disclosure measures except relational capital disclosure. These results imply that frequency of board meetings is an important factor in enhancing IC disclosure in order to reduce information asymmetry. The coefficient of CEO duality is found to be significantly related to relational capital disclosure while no significant impact of CEO duality on overall IC disclosure, human capital disclosure and structural capital disclosure at 0.05 significance level. In all coefficients, the controlling variable firm age and leverage have a positive and significant

\section{Table 5 : Regression results}

\begin{tabular}{|l|l|l|l|l|}
\hline & $\begin{array}{c}\text { Model 1 } \\
\text { ICDI }\end{array}$ & $\begin{array}{c}\text { Model 2 } \\
\text { HICDI }\end{array}$ & $\begin{array}{c}\text { Model 3 } \\
\text { SICDI }\end{array}$ & $\begin{array}{c}\text { Model 4 } \\
\text { RICDI }\end{array}$ \\
\hline Constant & 2.293 & 2.331 & 1.267 & 3.562 \\
\hline & $(0.000)$ & $(0.000)$ & $(0.082)$ & $(0.000)$ \\
\hline Board size & 2.310 & 1.619 & 1.748 & 3.512 \\
\hline & $(0.023)$ & $(0.108)$ & $(0.038)$ & $(0.001)$ \\
\hline Independent directors & 2.224 & 3.415 & 2.349 & 2.192 \\
\hline & $(0.041)$ & $(0.000)$ & $(0.027)$ & $(0.045)$ \\
\hline Board meetings & 2.898 & 2.115 & 1.111 & 1.251 \\
\hline & $(0.005)$ & $(0.037)$ & $(0.027)$ & $(0.061)$ \\
\hline CEO duality & 0.806 & 1.700 & 1.026 & 1.889 \\
\hline
\end{tabular}




\begin{tabular}{|l|l|l|l|l|}
\hline Firm age & $(0.237)$ & $(0.092)$ & $(0.071)$ & $(0.047)$ \\
\hline & 1.099 & 2.266 & 2.610 & 1.305 \\
\hline Leverage & $(0.274)$ & $(0.031)$ & $(0.010)$ & $(0.195)$ \\
\hline & 0.765 & 2.037 & 2.750 & 1.356 \\
\hline R & $(0.446)$ & $(0.044)$ & $(0.007)$ & $(0.178)$ \\
\hline R Square & 0.536 & 0.388 & 0.366 & 0.413 \\
\hline F & 0.287 & 0.151 & 0.134 & 0.170 \\
\hline Sig & 7.457 & 3.281 & 2.867 & 3.802 \\
\hline & 0.000 & 0.005 & 0.012 & 0.002 \\
\hline
\end{tabular}

\section{Concluding remarks}

This study aims to investigate the relationship between corporate governance and IC disclosure of listed Sri Lankan firms. Focussing on the board size, the mean size is approximately 12 directors and that has a significant positive effect on IC disclosure. It seems that boards with more members that in turn are more connected with the environment tend to disclose more on IC disclosure, thus the results affirm the assertion that $\mathrm{H} 1$ : There is a significant relationship between the size of the board and IC disclosures. The average proportion of independent director is 77 percent. On whole, the study observes that 92 percent firms compliance with recommendation of the Sri Lankan best practices (2017). The proportion of independent directors is significantly associated with all IC measures at the five percent level. Consistent with previous studies, the results highlight the fact that having independent directors play an active role and monitor insiders' activity on the committees lowers the need to reduce information asymmetries by means of disclosure policy (Abeysekera, 2008), thus supporting H2: There is a significant relationship between the proportion of independent directors and IC disclosures. The results for number of board meetings are positive and significant on IC disclsoure except relational capital disclosure at five percent level. The sudy also notes that board meet, on averge, about five times per year. This number of meetings might be realted with the Sri Lankan culture, where social and personal relations are deeply rooted and play a significant role, thus $\mathrm{H} 3$ : There is a significant relationship between number of board meetings and IC disclosures is supported. The study reveals that CEO duality is not significantly associated with any of the IC disclosure measures except relational capital disclosure, the results support the findings of Abdullah (2004) who also fail to find detect significant relationship. Conversely, proponents of the CEO duality argue that combining these two roles provide a clear focus for objectives and operations (Anderson \& Anthony, 1986). 
Regarding the lack of significance of CEO duality, the results are in line with those obtained by García-Meca, Parra, Larrán, and Martínez (2005) which suggest that CEO duality is associated with more IC disclosure only in those environments which are more proactive to disclosing information, that is, in countries with and high legal enforcement, thus H4: There is a significant relationship between CEO duality and IC capital disclosure is not supported. The firm age is significant with human capital disclosure and structural capital disclosure at the five percent level. The positive coefficient indicates that experienced firm disclose more IC information. This result is consistent with empirical evidence on IC disclosure (e.g., García-Meca, Parra, Larrán, \& Martínez, 2005) and theoretical arguments including agency theory, signalling theory, capital market theory, and cost-benefit theory. Future research should consider including many countries. The effect of corporate governance on IC discloclure should be more fully examined in future research.

\section{References}

Abeysekera, I. (2008). Intellectual capital disclosure trends: Singapore and Sri Lanka. Journal of Intellectual Capital, 9(4), 723-737.

Abeysekera, I., \& Guthrie, J. (2005). An empirical investigation of annual reporting trends of intellectual capital in Sri Lanka. Critical Perspectives on accounting, 16(3), 151-163.

Ahmed Haji, A. (2015). The role of audit committee attributes in intellectual capital disclosures: Evidence from Malaysia. Managerial Auditing Journal, 30(8/9), 756-784.

Azeez, A. (2015). Corporate governance and firm performance: evidence from Sri Lanka. Journal of Finance, 3(1), 180-189.

Abdullah, N. (2004). Board composition, CEO duality and performance among Malaysian listed companies. Corporate Governance: The International Journal of Business in Society,, 4(4), 47-61.

Ahmed-Haji, A. (2015). The role of audit committee attributes in intellectual capital disclosures: Evidence from Malaysia. Managerial Auditing Journal, 30((8/9)), 756-784.

Anderson, C. A., \& Anthony, R. N. (1986). The new corporate directors: Insights for board members and executives. Wiley. 
Beattie, V., \& Thomson, S. J. (2007, June). Lifting the lid on the use of content analysis to investigate intellectual capital disclosures. In Accounting Forum (Vol. 31, No. 2, pp. 129-163). Elsevier.

Beekes, W., Pope, P., \& Young, S. (2004). The link between earnings timeliness, earnings conservatism and board composition: evidence from the UK. Corporate Governance: An International Review, 12(1), 47-59.

Boyd, B. (1995). CEO duality and firm performance: A contingency model. Strategic Management Journal, 16(4), 301-312.

Brickley, J., \& James, C. (1987). The takeover market, corporate board composition, and ownership structure: The case of banking. The Journal of Law and Economics, 30(1), 161-180.

Bueno, E., Salvador, P., Rodríguez, O., \& Martín-de-Castro, G. (2004). Internal logic of the interactions among intangibles in a model of intellectual capital: The cognitive neuron of the intellects Model. IC Congress. Helsinki.

CA. (2017). Code of Best Practice on Corporate Governance . Colombo: CA Sri Lanka.

Cadbury Committee (1992). Report of the committee on financial aspects of corporate governance, London, HMSO.

Datta, D., \& Rasheed, A. (1991). 'Diversification and Performance: Critical Review and Future Directions', 28(5),. Journal of Management Studies, 28(5), 529-558.

Donaldson, L., \& Davis, J. (1991). Stewardship theory or agency theory: CEO governance and shareholder returns. Australian Journal of Management, 16(1), 49-64.

Datta, D., \& Rasheed, A. (1991). 'Diversification and Performance: Critical Review and Future Directions', 28(5),. Journal of Management Studies, 28(5), 529-558.

Dimmaggio, P., \& Powell, W. (1983). The iron cage revisited: Institutional isomorphism and collective rationality in organizational fields. American Sociological Review, 48(2), 147-160.

Eng, L., \& Mak, Y. (2003). Corporate governance and voluntary disclosure. Journal of Accounting and Public Policy, 22(4), 325-345.

Epps, R., \& Cereola, S. (2008). Do institutional shareholder services (ISS) corporate governance ratings reflect a company's operating performance? Critical Perspectives on Accounting, 19(8), 1135-1148.

Forker, J. (1992). Corporate governance and disclosure quality. Accounting and Business Research, 22(1), 111-124. 
Forbes, D., \& Milliken, F. (1999). Cognition and corporate governance: Understanding boards of directors as strategic decision-making groups. Academy of Management Review, 24(3), 489-505.

García-Meca, E., Parra, I., Larrán, M., \& Martínez, I. (2005). The explanatory factors of intellectual capital disclosure to financial analysts. European Accounting Review, 14(1), 63-94.

Goodstein, J., Gautam, K., \& Boeker, W. (1994). The effects of board size and diversity on strategic change. Strategic Management Journal, 15(3), 241-250.

Guo, Z., \& Kga, U. (2012). Corporate governance and firm performance of listed firms in Sri Lanka. Procedia-Social and Behavioral Sciences, 40, 664-667.

Guthrie, J., Petty, R., Ferrier, F., \& Wells, R. (1999). There is no accounting for intellectual capital in Australia: a review of annual reporting practices and the internal measurement of intangibles. OECD Symposium on Measuring and Reporting, (pp. 9-11). Australia.

Guest, P. (2008). The determinants of board size and composition: Evidence from the UK. Journal of Corporate Finance, 14(1), 51-72.

Hidalgo, R., García-Meca, E., \& Martínez, I. (2011). Corporate governance and intellectual capital disclosure. Journal of Business Ethics, 100(3), 483-495.

Jackling, B., \& Johl, S. (2009). Board structure and firm performance: Evidence from India's top companies. Corporate Governance: An International Review, 17(4), 492-509.

Jensen, M., \& Meckling, W. (1976). Theory of the firm: Managerial behavior, agency costs and ownership structure. Journal of Financial Economics, 3(4), 305-360.

Lemmon, M., \& Lins, K. (2003). Ownership structure, corporate governance, and firm value: Evidence from the East Asian financial crisis. The Journal of Finance, 58(4), 1445-1468.

Lipton, M., \& Lorsch, J. (1992). A modest proposal for improved corporate governance. The Business Lawyer, 59-77.

Lorsch, J., \& MacIver, E. (1989). Pawns or potentates: The reality of America's corporate boards. Boston: Harvard Business School.

Li, J., Mangena, M., \& Pike, R. (2012). The effect of audit committee characteristics on intellectual capital disclosure. The British Accounting Review, 44(2012), 98110 .

Markarian, G., Parbonetti, A., \& Previts, G. (2007). The convergence of disclosure and governance practices in the world's largest firms. Corporate Governance International Review, 15(2), 294-308. 
McKinnon, J., \& Dalimunthe, L. 1. (1993). Voluntary disclosure of segment information by Australian diversified companies. Accounting and Finance, 33(1), 33-50.

Macus, M. (2008). Board capability; An interactions perspective on boards of directors and firm performance. International Studies of Management \& Organization, 38(3), 98-116.

McCullers, L., \& Schroeder, R. (1982). Source and methodology of accounting principles. In Accounting theory, text and readings (pp. 2-27). New York: Wiley.

Pfeffer, J. (1972). Size and composition of corporate boards of directors: The organization and its environment. Administrative Science Quarterly, 218-228.

Pratheepkanth, P., Hettihewa, S., \& Wright, C. (2016). Corporate governance and financial performance: The case of Australia and Sri Lanka. 7(1), 1-12.

Ramanujan, V., \& Varadarajan, P. (1989). Research on corporate diversification: a synthesis. StrategicManagement Journal, 10, 523-551.

Shleifer, A., \& Vishny, R. (1997). A survey of corporate governance. The Journal of Finance, 5(2), 737-783.

Welford, R. (2007). Corporate governance and corporate social responsibility: issues for Asia. Corporate Social Responsibility and Environmental Management, 14(1), 42-51.

Wild, J. (1996). The audit committee and earnings quality. Journal of Accounting, Auditing \& Finance, 11(2), 247-276.

Vafeas, N. (1999). Board meeting frequency and firm performance. Journal of financial economics, 53(1), 113-142.

Van den Berghe, L. A., \& Levrau, A. (2004). Evaluating boards of directors: what constitutes a good corporate board?. Corporate Governance: an international review, 12(4), 461-478.

Yermack, D. (1996). Higher market valuation of companies with a small board of directors. Journal of Financial Economics, 40(2), 185-211. 